\title{
Hermann Karsten, pioneer of geologic mapping in northwestern South America
}

\author{
K. R. Aalto \\ Department of Geology, Humboldt State University, Arcata, CA 95521, USA \\ Correspondence to: K. R. Aalto (kra1@humboldt.edu)
}

Received: 08 October 2014 - Revised: 03 June 2015 - Accepted: 07 June 2015 - Published: 25 June 2015

\begin{abstract}
In the late 19th century, a regional map of Nueva Granada (present-day Colombia, Panama and parts of Venezuela and Ecuador) was published by German botanist and geologist Hermann Karsten (1817-1908). Karsten's work was incorporated by Agustín Codazzi (1793-1859), an Italian who emigrated to Venezuela and Colombia to serve as a government cartographer and geographer, in his popular Atlas geográfico e histórico de la Republica de Colombia (1889). Geologic mapping and most observations provided in this 1889 atlas were taken from Karsten's Géologie de l'ancienne Colombie bolivarienne: Vénézuela, Nouvelle-Grenade et Ecuador (1886), as cited by Manual Paz and/or Felipe Pérez, who edited this edition of the atlas. Karsten defined four epochs in Earth history: Primera - without life - primary crystalline rocks, Segunda - with only marine life chiefly sedimentary rocks, Tercera - with terrestrial quadrupeds and fresh water life forms life - chiefly sedimentary rocks, and Cuarta - mankind appears, includes diluvial (glacigenic) and post-diluvial terranes. He noted that Colombia is composed of chiefly of Quaternary, Tertiary and Cretaceous plutonic, volcanic and sedimentary rocks, and that Earth's internal heat (calor central) accounted, by escape of inner gases, for volcanism, seismicity and uplift of mountains. Karsten's regional mapping and interpretation thus constitutes the primary source and ultimate pioneering geologic research.
\end{abstract}

\section{Introduction}

Following pioneering exploration and publication of travel memoirs by the great naturalist Alexander von Humboldt (1769-1859), several European naturalists with geologic expertise catalogued fossil and mineral finds on route maps through northwest South America (summarized in Boussingault, 1849; Rivero y Ustariz, 1857). The Italian-born military geographer, Agustín Codazzi (1793-1859), incorporated findings of von Humboldt (1816) and other early 19th century naturalists in his writings on Nueva Granada (presentday Colombia, Panama and parts of Venezuela and Ecuador; Codazzi, 1840, 1844; Codazzi et al., 1889). His widely circulated texts established him as a premier geographer/naturalist of his era. However, Codazzi's geologic map of Nueva Granada was largely derived from that published in 1886 by Hermann Karsten (1817-1908), who should be accredited as the foremost pioneering geologist of this region.

\section{Karsten's predecessors}

Naturalists of the late 17th and early- to mid-19th centuries who are cited as sources of geologic information by Karsten include Alexander von Humboldt, Jean-Baptiste Boussingault (1802-1887), Mariano Eduardo de Rivero y Ustariz (1798-1857) and Agustín Codazzi (Fig. 1). These men traveled extensively through the Andes noting economic mineral resources, general lithology, hydrothermal and spring activity and physical geographic data. Fossil collections sent to European specialists contributed to age discrimination of geologic formations (e.g., von Buch, 1839). Annotated sketch maps of routes traveled provided some degree of control for subsequent geologic mapping. Boussingault, a French agricultural scientist and chemist, traveled through Peru and Ecuador, ascended the Chimborazo volcano in 1831, collected fossils for age determination, and assessed mineral resources (Boussingault, 1849). Rivero y Ustariz, a prominent Peruvian mineralogist and chemist who dabbled in archeology, mineral exploration and politics, was a pioneer of min- 


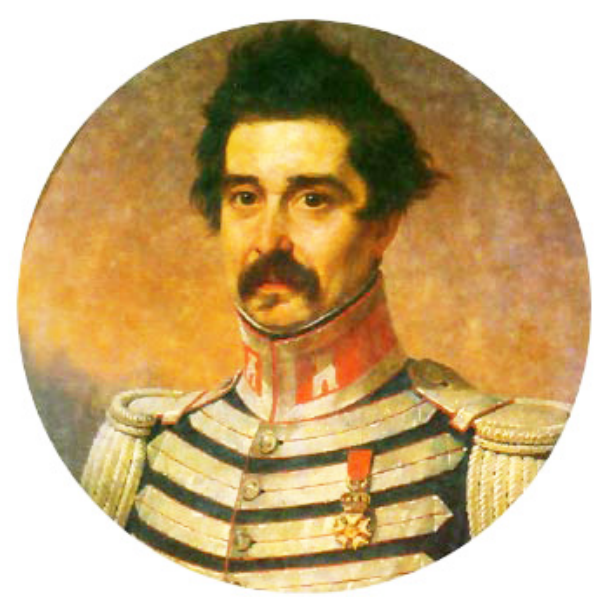

Figure 1. Portrait of Agustín Codazzi (http://www. biografiasyvidas.com/biografia/c/codazzi.htm).

ing education in Peru, Colombia and Chile (Rivero y Ustariz, 1857). Both were cited as primary sources by Codazzi in his extensive geographic studies. Wall and Sawkins (1860) published a geologic sketch map with geologic sections across Trinidad and part of northern Venezuela which showed considerable folding and faulting among basement rocks. They described the oldest basement rocks (the "Caribbean System") as "a series of micaceous and siliceous schists, ... sandstones ... and shales" (Wall and Sawkins, 1860, p. 462).

Agustín Codazzi is acknowledged as the premier 19th century geographer in northwestern South America (Magnani, 1881; Perazzo, 1956; Sánchez y Efraín, 1993). Codazzi was born in Italy and trained at a military college in Bologna. He then joined Napoleon's army serving as a soldier. Following Napoleon's defeat in 1814, he became a merchant and eventually turned his attention to opportunities in the New World, serving as a military engineer and cartographer under Simón Bolivar in the wars of independence from Spain. He eventually emigrated, first to Venezuela and later Colombia, employed as a government cartographer and geographer (Magnani, 1881). His Atlas físico y político de la República de Venezuela (1840) and Resúmen de la geografía de Venezuela (1844), for which he was awarded the French Légion d'honneur, and his Atlas geográfico e histórico de la Republica de Colombia (1889) provided geographic, economic, political, cultural and social commentary with accurate data on elevations, waterways, and many important geographical, physical and statistical details (Perazzo, 1956).

Codazzi organized the Comisión Corográfica (1850) which utilized geographic data to foster national development. Magnani (1881, p. "a") notes that only with "an immense effort, with countless hardships, could he obtain for his study all necessary data relating to geography, the ethnography, history and Indian archeology, with itineraries, opening roads, barometric astronomical determinations, and land surveys and statistics" ("un inmenso trabajo e innumerables fatigas pudo adquirir para su obra todas las noticias necesarias relativas a la geografía, a la etnografía, a la historía y a la arqueología indianas, con itinerarios, a la apertura de caminos, a determinaciones astronomicas barometricas, y catastros y estadistica") (Unless otherwise noted, all translation are my own.). Alexander von Humboldt described the geographic works of Codazzi in Venezuela as "milestones in the history of science" (Sánchez y Efraín, 1993; Gómez, 2014). However, the majority of reports published by this commission merely listed mineral resources without reviewing their geologic setting (e.g., Perez, 1863).

Other than an occasional listing of resources, fossils found and soil characteristics, Codazzi's works on Venezuela provide little of geologic interpretation or mapping (Codazzi, 1840, 1844). However, the 1889 Atlas Geográfico e Histórico de la República de Colombia provides interpretive profiles (Fig. 2), a geologic map (Fig. 3), and several-page discussion of stratigraphy and interpretation. Terminology reflects the persistence of quasi-Wernerian stratigraphic terminology throughout the 19th century, despite the use of fossils as biostratigraphic indicators. It is of note that these geologic contributions appeared posthumously with respect to Codazzi and that Hermann Karsten is cited as the source for these data. An earlier edition of this atlas contains no geologic maps (Codazzi et al., 1865). Apparently, co-author(s) Manual Paz and/or Felipe Pérez added this additional material, noting that "[f]or a more in-depth study, one should consult the important work of Herman [sic] Karsten on the geology of ancient Colombia ... and dedicated by the author to Colombians" ("Para un estudio más serio, debe consultarse la importante obra de Herman Karsten sobre la geología de la antigua Colombia ... y dedicada por su autor á los colombianos") (Codazzi et al., 1889, p. 22). In summary, they note that the territory of Colombia consists chiefly of Cretaceous, Tertiary and Quaternary terranes, which include sedimentary, plutonic and volcanic rocks. Diluvial deposits consist exclusively of mixed, unstratified sand and gravel, accompanied by erratic blocks. These are found on the summit of the hills and on plains that have no running water and cannot be attributed to deposition by modern rivers (Codazzi et al., 1889). Suggesting a geothermal gradient of $1^{\circ}$ for every $27 \mathrm{ft}$. of depth, they speculate that

everything should be fluid and incandescent, and we see that at 20 or 25 leagues in depth, ... nothing compared to the 1,500 leagues from the surface to the center of the earth ("todo debe ser fluido é incandescente; y bien se ve que 20 ó 25 leguas de profundidad, no son nada respecto de las 1,500 leguas que dista el centro de la tierra de la superficie de ésta"). From the theory of the [Earth's] central heat we derive uplift, the origin of the mountains. These uplifts are produced by the inner gases, which tend to escape from within the planet and produce volcanoes, mountains, large 


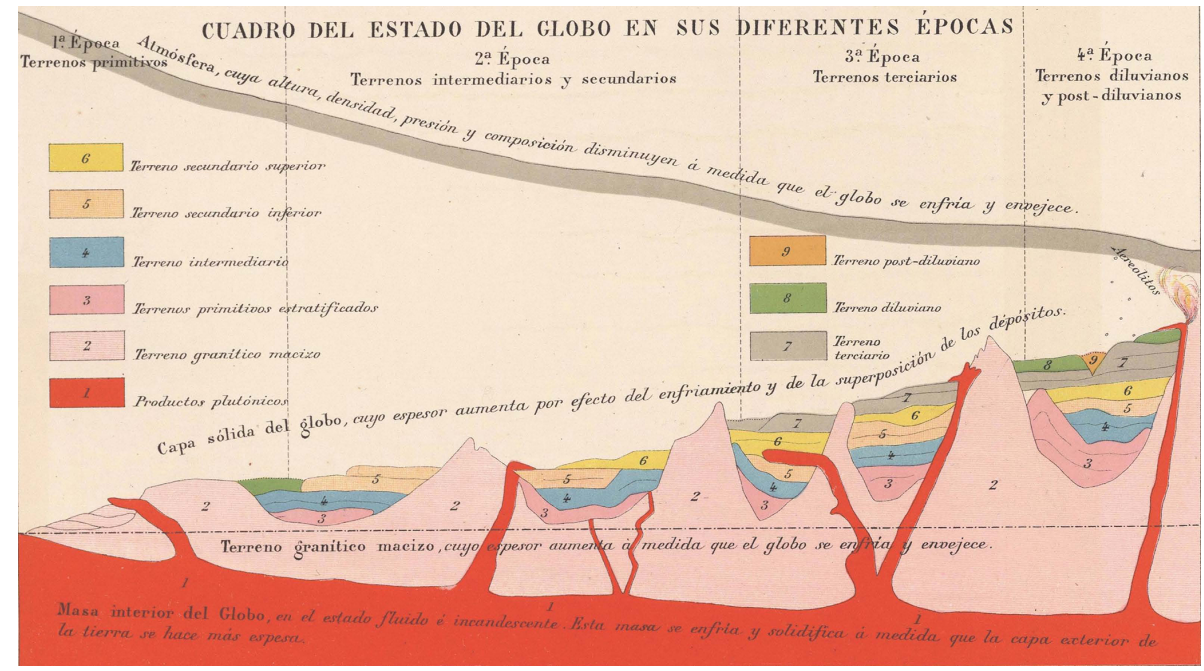

Figure 2. State of the earth through time. Numbered key: 1 - plutonics (fused), 2 - granitic terrane, 3 - stratified primitive terrane, 4 intermediary terrane, 5 - lower secondary terrane, 6 - upper secondary terrane, 7 - Tertiary terrane, 8 - diluvial terrane, 9 - post-diluvial terrane. Note the transition from the first epoch (primitive terrane), to the second (secondary and intermediary terranes), to the third (Tertiary terranes), to the fourth (diluvial and post-diluvial terranes). From left to right, the stratigraphic column builds upon a "granitic terrane [pink], whose thickness increases as the earth ages and cools" ("terreno granítico macizo, cuyo espesor aumenta a medida que el globo se enfría y envejece"). The dashed line is present sea level. Above this line is a "[g]lobal solid layer whose thickness increases the effect of cooling and superposition of deposits" ("Capa sólida del globo, cuyo espesor aumenta por efecto del enfriamiento y de la superposición de los depósitos"). "Inside the globe, in the fluid state and [is an] incandescent mass [red]. "This mass is cooled and solidifies along with the outer layers of the earth" ("Masa interior del Globo, en el estado fluido é incandescente. Esta masa se enfría y solidifica á medida que la capa exterior de la tierra se hace mas espera"). Note feeder dikes emanating from this mass, the magma source for volcanoes. At the top is the "[a]tmosphere, whose height, density, pressure and composition decrease as the earth is cooled and aged" ("Atmósfera, cuya altura, densidad, presión y composición disminuyen á medida que el globo se enfría y envejece”) (Codazzi et al., 1889, plate XVI).

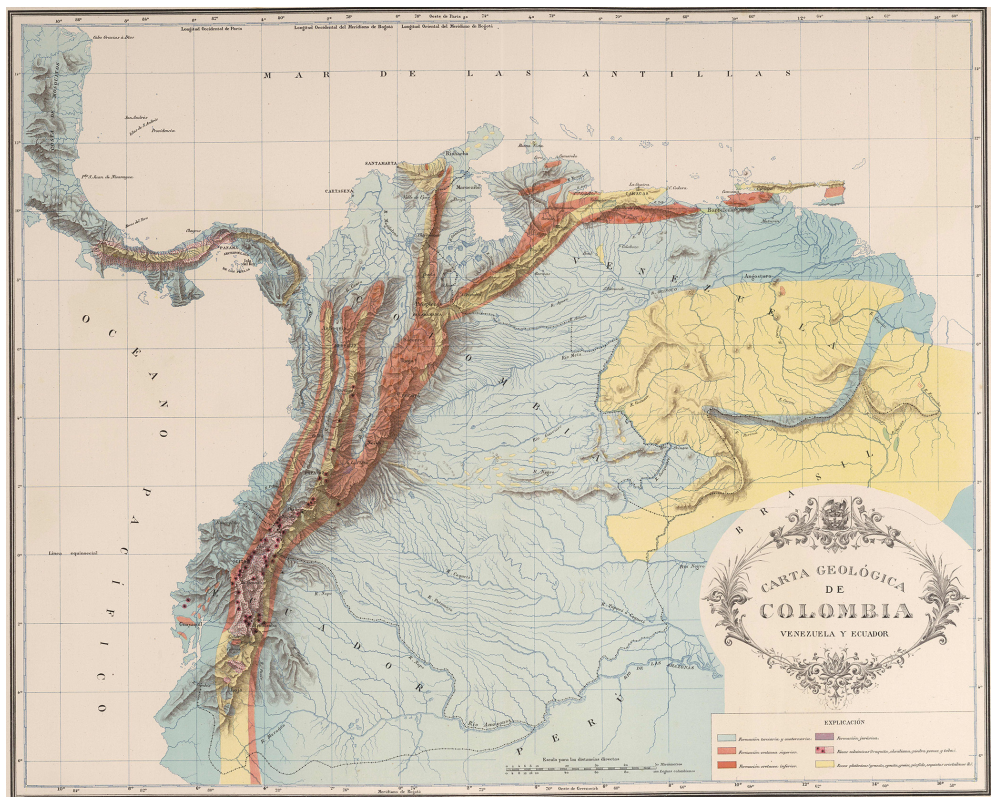

Figure 3. Geologic map of Colombia (Codazzi et al., 1889, plate XVII). Key: light blue - Tertiary and Quaternary, lighter orange - Upper Cretaceous, darker orange - Lower Cretaceous, purple - Jurassic, pink with asterisks - volcanoes, dotted pink - miscellaneous volcanic rocks, yellow - plutonic rocks. 


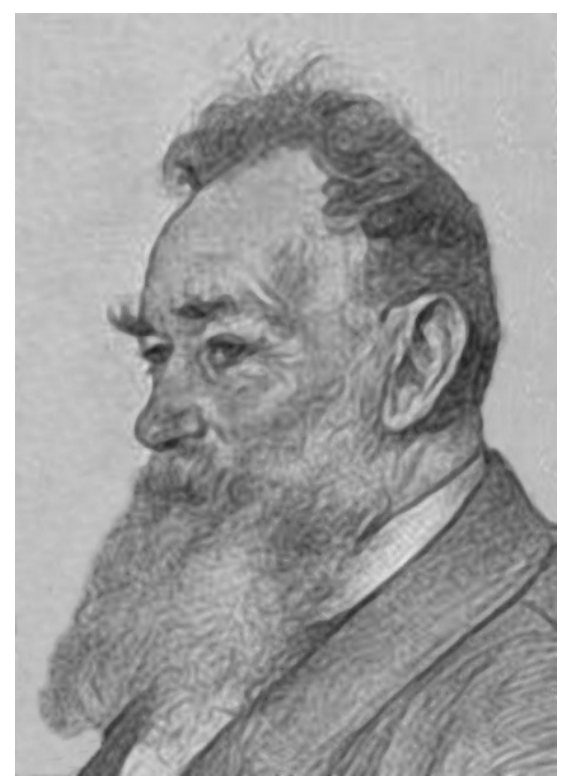

Figure 4. Portrait of Hermann Karsten (https://de.wikipedia.org/ wiki/Hermann_Karsten).

cracks and other dislocations. These gases are also the cause of earthquakes. ("Del principio del calor central se desprende la teoria de los levantamientos, origin de las montanas. Estos levantamientos son producidos por los gases interiores, que tienden a escaparse del seno del planeta y producen los volcanes, las montañas, las grandes grietas y otras dislocaciones. Estos gases son también la causa de los terremotos"). (Codazzi et al., 1889, p. 22)

\section{Gustav Karl Wilhelm Hermann Karsten}

Hermann Karsten (Fig. 4) was a German botanist and geologist. His "geologic studies are all the more remarkable when it is realized that he was primarily a botanist" (Hedberg, 1974, p. 32). Apprenticed to a pharmacist and later educated in natural science, including mineralogy, at the University of Rostock (1839-1841), he became interested in plant physiology and received his doctorate at Frederick Wilhelm University in Berlin in 1842 (Hedberg, 1974; Alert, 1999). From 1844 to 1856 he traveled extensively throughout the northern part of South America engaged chiefly in the study of tropical plants. Von Humboldt provided him with a letter of introduction to the Venezuelan government which welcomed his research (Alert, 1999). He benefited from contact with Codazzi's cartographer, Alexander Benitz (1813-1869), who perhaps provided him with his latest maps (Hedberg, 1974).

During his extensive travels throughout northwestern South America he collected geological, as well as botanical, data. From 1854 to 1856 he traveled through Colombia and Ecuador, returning to Germany in 1856 (Hedberg, 1974). Karsten received no financial support for his 12 years of field investigation, "but after I finished my research ... I was commissioned by the government of Bogota ... to write a geognostical description of New Granada" ("mais après que j'eus terminé mes recherches, ... je fus chargé par le gouvernement de Bogotá, ... de rédiger une description géognostique de la Nouvelle Grenade"), for which he never received the promised stipend (Karsten, 1886, p. 6). Upon returning to Europe, he was first a professor at the Agricultural Research Institute in Berlin (1856-1868), then a professor of plant physiology at the University of Vienna (1868-1872) where he established a plant physiological laboratory. $\mathrm{He}$ published on the age of geologic formations in Europe and undertook geologic studies on Capri and throughout his career interacted with many German botanists and geologists who undertook South American research (Hedberg, 1974; Alert, 1999).

Karsten's geological publications, including letters, range from 1849 (on Venezuelan Cretaceous rocks with remains of Megatherium) to 1890 (Karsten, 1850, 1852, 1862, 1874; Hedberg, 1974). From climbs of Andean stratovolcanoes, he determined "that the high valley of the Cordilleras contains countless outpourings of lava flows and tuff, such that it would be wrong to view andesite colossi of the Andes as a homogeneous mass" ("dass das ganze Hochthal der Cordilleren aus zahllosen Ergüssen von Lavaströmen und Tuff massen besteht, dass es eine falsche Ansicht sein würde, sich die Andesit kolosse der Anden als homogene Massen zu denken") (Karsten, 1874, p. 568). He used fossils to identify extensive Cretaceous formations that are a source for Tertiary conglomerates in central Venezuela, speculated that Cretaceous sedimentary strata grade laterally into metamorphic rocks, and thus rocks that are apparently "plutonic ... originate not out of the depths but have their origin from the alteration of existing bedded rocks ... [with] all stages of change from the coarsest plutonic rocks to the simple neptunic sediments" (Hedberg, 1974, p. 39). In summary, the geology of northwestern South America appeared to consist of four principal formations:

1. The Older Cretaceous, characterized by many ammonites. 2. The Younger Cretaceous, characterized by thick sandstone and chert strata and often highly foraminiferal. 3 . The Tertiary which is ... widespread $\ldots$ but is poor in organic remains and marked by the coming in of boulder beds [with] indications of derivation from older strata. 4. Quaternary deposits of rubble and mollusk beds. (Hedberg, 1974, p. 41)

He concluded that Andean uplift occurred in the late Tertiary, based upon the presence of "a yet living species of Pholas at a height of 3,000 ft." in the mountains of Colombia and Ecuador (Hedberg, 1974, p. 42). 


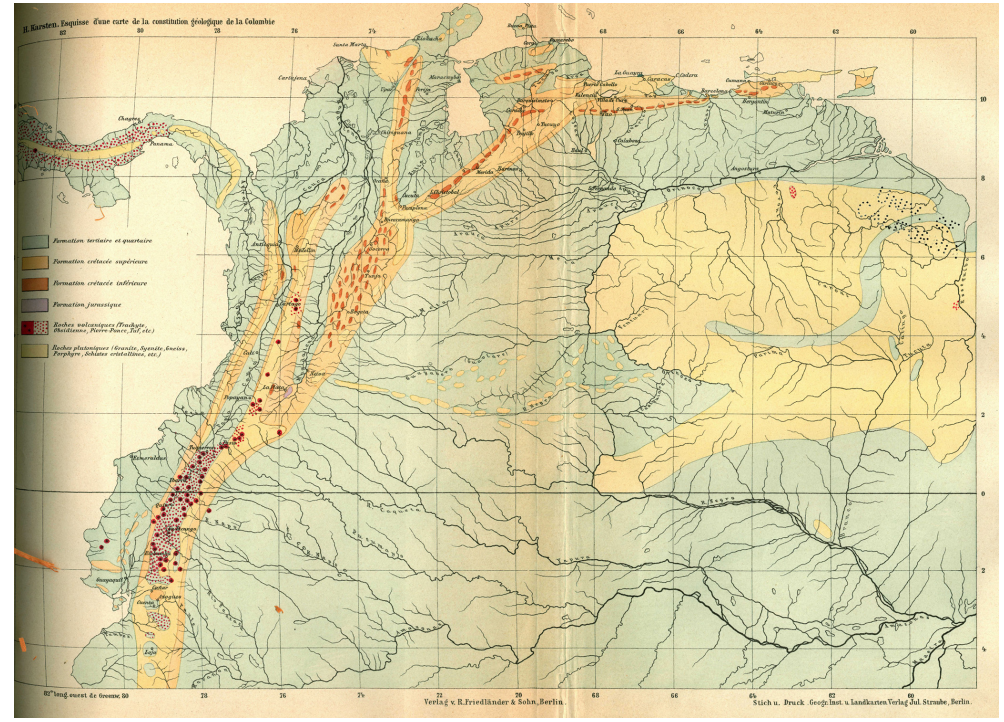

Figure 5. Karsten's 1886 geologic map of Colombia. Key: light blue - Tertiary and Quaternary, lighter orange/yellow - Upper Cretaceous, darker orange/yellow - Lower Cretaceous, light purple - Jurassic, pink with asterisks - volcanoes, dotted pink - miscellaneous volcanic rocks, yellow - plutonic rocks (granite, syenite, gneiss, porphyry, crystalline schists [sic], etc.).

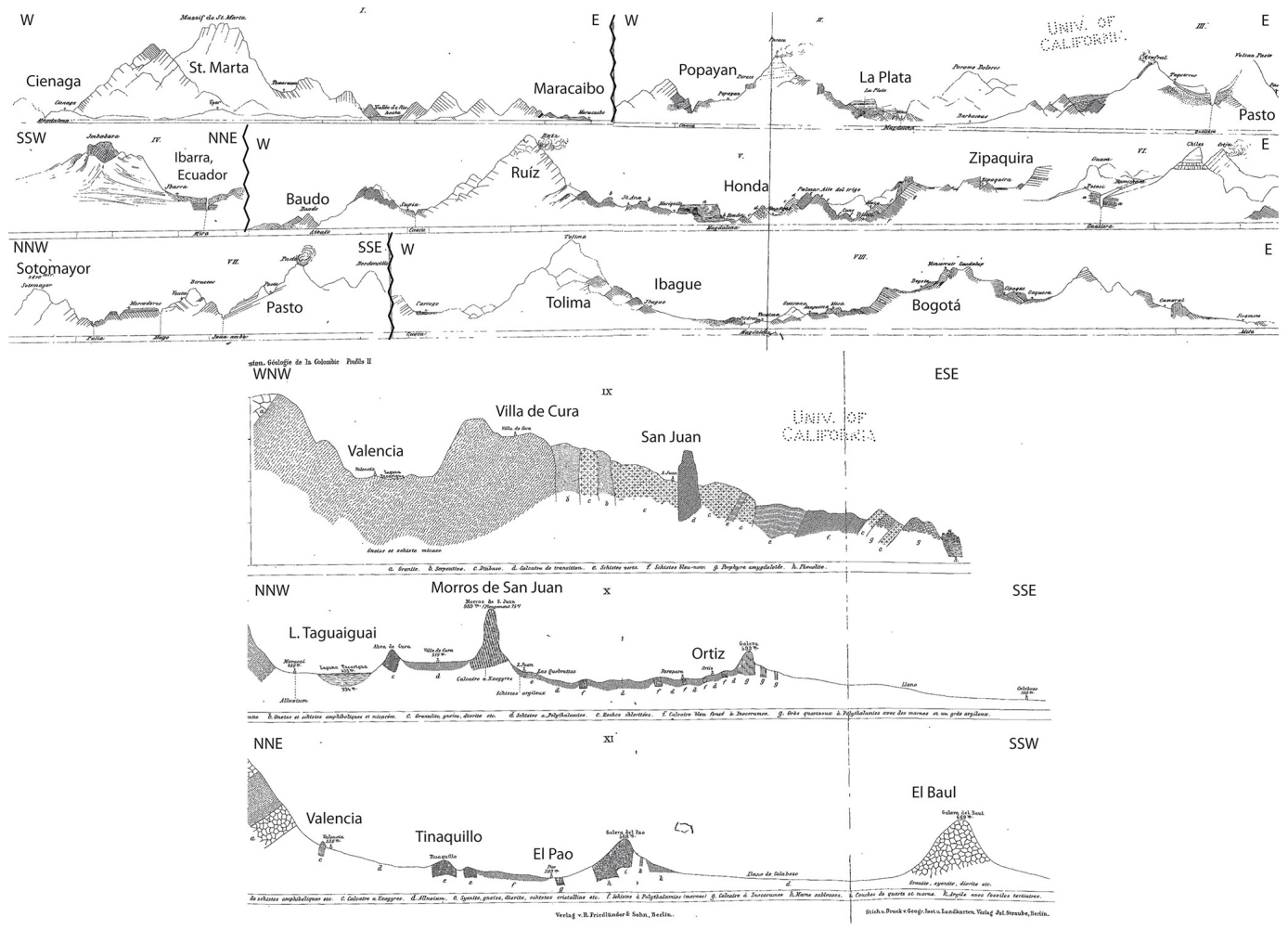

Figure 6. Karsten's 1886 geologic profiles across parts of Colombia, Venezuela and Ecuador. Additions of place names and approximate geographic coordinates made by Aalto for clarity. Vertical zigzag lines separate different profiles. Approximate bedding orientation for layered rocks is shown beneath the land profiles. Active volcanoes are given plumes. Lithologies are given in fine print beneath the lower three profiles, all near Valencia, Venezuela. 
Karsten offered his 1886 treatise, Géologie de l'ancienne Colombie bolivarienne: Vénézuela, Nouvelle-Grenade et Ecuador, as the "first beginning of a geognostical description of this area" ("premier commencement d'une description géognostique de cette région") (Karsten, 1886, p. 1). He reviewed earlier geologic studies, including references to many fossil identifications undertaken in Europe. His geologic map (Fig. 5) was the source of the Codazzi et al. (1889), plate XVII. His geologic profiles (Fig. 6) depict lithostratigraphic relations in parts of Colombia, Venezuela and Ecuador, showing orientations of layered rocks, generalized topography and lithology. This 1886 treatise is written in an anecdotal itinerary style, with comments on climate, topography, vegetation, soil conditions and all aspects of geology at thousands of scattered locations and with minimal organization. He does occasionally summarize, as follows:

Throughout the territory explored so far, we find no trace of the Palaeozoic series; old names "Old Red Sandstone" and "Carboniferous" [are] false determinations based on lithologic analogies; indeed, coal and red sandstone in Colombia Bolivar, belong to the most recent series, that is to say, in the Late Cretaceous or Tertiary. ... Conscientious future studies should determine whether [more] ancient lands did not really exist in this country; or ... if they were represented but were rendered unrecognizable by the action of plutonic agents, and transformed into crystalline schists. Sedimentary deposits of all regions explored and described so far belong almost without exception to the Cretaceous, Tertiary and Quaternary ("Dans tout le territoire exploré jusqu'ici nous ne trouvons aucune trace de la série paléozoïque; les vieilles dénominations de 'Vieux grès rouge', et de "Carbonifère" reposent sur des déterminations fausses faites d'après des analogies de la roche; en effet le charbon et le grès rouge, dans la Colombie de Bolivar, appartiennent à la série la plus récente, c'està-dire au Crétacé supérieur ou au Tertiaire. ... Des études ultérieures consciencieuses devront vérifier si ces terrains anciens ne se sont vraiment pas déposés dans cette contrée; ou ce, qui est plus probable, s'ils y étaient représentés mais ont été rendus méconnaissables par l'action des agents plutoniques, et métamorphosés en schistes cristallins. Les dépôts sédimentaires de toute la région explorée et décrite jusqu'à maintenant appartiennent donc presque sans exception au Crétacé, au Tertiaire et au Quaternaire.”) (Karsten, 1886, p. 46)

\section{Summary}

The Codazzi et al. (1889) atlas was widely distributed; thus, Karsten's geologic mapping remained a primary source for future exploration (Hedberg, 1974). Codazzi was a true pioneer as a consummate geographer, covering all political, ethnologic, commercial, agricultural and climatic as well as geographic features of Nueva Granada during his lifetime career in his newly adopted country. However, his geologic training was minimal and chiefly focused upon listing economic resources. With the addition of Hermann Karsten's geologic mapping and interpretation subsequent to Codazzi's death, the Atlas Geográfico e Histórico de la República de Colombia excelled as a primary data source throughout the late 19th and early 20th centuries, and is still cited in current research papers (e.g., Schemm-Gregory et al., 2012).

Acknowledgements. I thank the Earth Sciences \& Map Library, University of California, Berkeley, for providing Karsten's map (Fig. 5). Maps and vertical sections of Figs. 2 and 3 are available online courtesy of map collector David Rumsey (http://www.davidrumsey.com/). Most 19th century reports cited are available on Google Books. I thank two anonymous reviewers for suggestions and corrections.

Edited by: J. Urrutia-Fucugauchi

Reviewed by: two anonymous referees

\section{References}

Alert, A.: Bajo los trópicos, Hermann Karsten y Franz Engel en América del Sur, in: Alemanes en las Regiones Equinocciales: Libro Homenaje al Bicentenario de la Llegada de Alexander von Humboldt a Venezuela, 1799-1999, edited by: Rodroguez, J. A., ALFA Grupo Editorial, Caracas, Venezuela, 142-160, 1999.

Boussingault, J.: Viajes Científicos a los Andes Ecuatoriales o Colección de Memorias sobre Física, Química e Historia Natural de la Nueva Granada, Ecuador y Venezuela, Paris, Librería Castellana, 326 pp., 1849.

Codazzi, A.: Atlas Físico y Político de la República de Venezuela, Lithographie de Thierry Frères, París, 30 pp., 20 plates, 2 pp., 28 plates, 1840.

Codazzi, A.: Resúmen de la Geografía de Venezuela, H. Fournier y Co., Paris, 648 pp., 1844.

Codazzi, A., Paz, M. M., and Pérez, F.: Atlas de los Estados Unidos de Colombia, antigua Nueva Granada, Manuel Ponce de León i Manuel María Paz. Paris, 690 pp., 1865.

Codazzi, A., Paz, M. M., and Pérez, F.: Atlas Geográfico e Histórico de la República de Colombia, A. Lahure, Paris, 25 pp., 21 plates, 1889.

Gómez, G. L.: Agustín Codazzi, Biografías Gran Enciclopedia de Colombia del Círculo de Lectores, available at: http://www. banrepcultural.org/blaavirtual/biografias/codaagus.htm (last access: 22 June 2015), 2014.

Hedberg, H. D.: Hermann Karsten, Pioneer geologist in northern South America, 1844-1856, Verhandl. Naturf. Ges. Basel, 84, 32-44, 1974. 
Karsten, H.: Beitrag zur Kenntniss der Gesteine des nördlichen Venzuela, Z. Dtsch. Geol. Ges., 2, 345-361, 1850.

Karsten, H.: Geognostische Bemerkungen über die Nordküste NeuGranada's, insbesondere über die sogenannten Vulkane von Turbaco und Zamba, Z. Dtsch. Geol. Ges., 4, 579-583, 1852.

Karsten, H.: Die geognostische Beschaffenheit der Gebirge der Provinz Caracas, Z. Dtsch. Geol. Ges., 14, 282-287, 1862.

Karsten, H.: Herr Hermann Karsten an Herrn G. vom Rath. Schaffhausen im Januar 1874, Z. Dtsch. Geol. Ges., 26, 568-572, 1874.

Karsten, H.: Géologie de L'ancienne Colombie Bolivarienne: Vénézuela, Nouvelle-Grenade et Ecuador, Berlin, R. Friedländer \& Sohn, 1886.

Magnani, D.: Biografía de Agustín Codazzi, Impr. de Gaitan, Bogotá, 29 pp., 1881.

Perazzo, N.: Agustin Codazzi (1793-1859), Biblioteca Escolar, Colección de Biografías no. 22, Ediciones de la Fundación Eugenio Mendoza, Caracas, 62 pp., 1956.

Perez, F.: Jeografia Fisica and Politica de los Estados unidos Columbia II, Imprenta de la Nacion, Bogota, 650 pp., 1863.
Rivero y Ustariz, M. de: Colección de Memorias Científicas, Agrícolas e Industriales Publicadas en Distintas Épocas, v. 1, Brussels, H. Goemaere, 292 pp., 1857.

Sánchez y Efraín, C.: Agustín Codazzi y la Geografía en el Siglo XIX, available at: http://www.banrepcultural.org/ blaavirtual/revistas/credencial/junio1993/junio1.htm (last access: 22 June 2015), 1993.

Schemm-Gregory, M., Rojas-Briceño, A., Patarroyo, P., and Jaramillo, C.: First report of Hadrosia Cooper, 1983 in South America and its biostratigraphical and palaeobiogeographical implications, Cretaceous Research, 34, 257-267, 2012.

Von Buch, L.: Pétrifications recueillies en Amérique par Alexandre de Humboldt et par Charles Degenhardt, Impr. de l'Académie royale des sciences, Berlin, 22 pp., 1839.

Von Humboldt, A.: Vues des Cordillères, et Monumens des Peuples Indigenes de L'Amérique, Librairie Crecque-Latine-Allemande, Paris, v. 1, 392 pp., v. 2, 332 pp., 1816.

Wall, G. P. and Sawkins, J. G.: On the geology of part of Venezuela and of Trinidad, J. Geol. Soc. London, 16, 460-470, 1860. 